Vaughan and Scarrow

\title{
K-rich mantle metasomatism control of localisation and initiation of lithospheric strike-slip faulting
}

\author{
Alan P.M. Vaughan ${ }^{1}$ and Jane H. Scarrow ${ }^{2}$ \\ ${ }^{1}$ British Antarctic Survey, High Cross, Madingley Road, Cambridge, CB30ET, United Kingdom \\ ${ }^{2}$ Dept. Mineralogía y Petrología, Campus Fuentenueva, University of Granada,18002 Granada, Spain.
}

${ }^{1}$ Tel. 01223221419

${ }^{1}$ Fax 01223362616

'e-mail: a.vaughan@bas.ac.uk

Abstract

A conceptual model is proposed where bulk transtension, or local transtension during bulk simple shear (resulting from mantle anisotropy- or lithosphere rheology contrasts), of heterogeneously enriched lithospheric mantle, trigger localised K-rich magmatism, which focusses strain and causes nucleation of lithosphere-scale transtensional or strike-slip shear zones. Transtension-triggered magmatism is most likely to be located at sites of maximum metasomatism of the lithospheric mantle. Magma-generated fractures propagate upwards, nucleating zones of lithospheric weakness, which focus shear in narrow transcurrent faults or at basin margins. In this way, magmatism controls fault timing and location. Although volcanism will be coeval with fault development and volcanoes will appear fault-controlled, counterintuitively, our model suggests that faults are, in a sense, volcano-controlled. We suggest that this new transtension-K-rich magmatism-transcurrent faulting association represents a hitherto unrecognised genetic relationship as significant as, for example, the ocean island magma series. 


\section{Introduction}

K-rich basalts and associated potassic plutonic rocks, of diverse tectonic contexts (Wilson 1989), are the shallow-level expressions of K-rich metasomatism of the lithospheric, i.e. nonconvecting, mantle (McKenzie 1989). This mantle is melted to form K-rich magmas in two main mantle thermal regimes: i. A high thermal regime associated with processes such as mantle plume impact, e.g., Paraná flood basalt province (Gibson et al. 1997; Fig. 1), lithospheric delamination, e.g., Harghita volcanic rocks, eastern Carpathians (Gîrbacea and Frisch 1998; Fig. 1), or lithospheric extension with $\beta$-factor $>2$, e.g., Rio Grande rift, USA (Gibson et al. 1993; Fig. 1), and ii. a low thermal regime where potassic mafic and felsic rocks are associated with transtension of the lithosphere; in many cases hosted by transtensional strike-slip shear zones, e.g., Caledonian shoshonitic magmatism, northern British Isles (Vaughan 1996; Fig. 1). Here we present a tectonomagmatic model for regime ii, arguing that heterogeneously metasomatized lithospheric mantle undergoes decompression during Type B transtension (Fossen and Tikoff 1998), either regionally, or locally due to deviations in stress trajectory, and melts to form potassic mafic magmas. Magma-driven fracturing focusses strain, controls the site of initiation and propagation of fault systems and, consequently, determines the local yield strength of the lithosphere.

Fault control of magmatism

Structural studies have suggested that pre-existing strike-slip fault systems can act as conduits for and create accumulation spaces for magma (e.g., Pe-Piper et al 1998). The subject of fault control of magmatism is a vast one and a comprehensive review is far outside the scope of this paper, however, a few key papers are worth summarising to give some indication of the depth of 


\section{Vaughan and Scarrow}

study and the range over which the relevant questions have been addressed. Links between regional deformation and magmatism were first proposed by Balk (1937) and in more detail by Anderson (1951). The modern debate on the links between magmatism and faulting has focussed mainly on granitic magma and began with work on the Donegal granite in northwest Ireland by Hutton (1982; thoroughly reviewed in Hutton 1988a). Recent important papers on granite emplacement include Hutton et al. (1990), Hutton \& Ingram (1994), Petford et al. (1996), Benn et al. (1998); for a counter argument view see Patterson \& Vernon (1995). Recently, anisotropy of magnetic susceptibility has emerged as a new and powerful technique for determining magma emplacement mechanisms (e.g. Bouchez 1997, Moyen 2003). For mafic magmatism, apart from the well-documented relationship between extension of $\beta$-factor $>2$ and basaltic magmatism (e.g. McKenzie \& Bickle 1988), there is a lot less, although dyke emplacement has been implicated in normal fault movement in rift zones (Rubin \& Pollard 1988) and mafic plutons in the Ivrea-Verbena zone of northern Italy appear to be syn-extensionally emplaced (e.g. Quick et al. 1994). We review the evidence for tectonic control of K-rich magmas below. In this paper, we turn the argument for fault control of magma emplacement on its head, and argue that in one major case, deep-seated magma genesis controls faulting.

Magmatism from K-rich metasomatized mantle and transtension

Structural emplacement settings for K-rich magmatism, where control is well known, can be summarised as follows: i. fault bends in strike-slip zones (e.g. Turkish Anatolian cinder cones, Adiyaman et al. 1998): ii. strike-slip fault terminations (e.g. Caledonian Strontian granite, Scotland; Hutton 1988b): iii. en echelon fissure systems (e.g. Caledonian lamprophyres; Vaughan 1996); iv. transverse structures in extensional zones (e.g. Virunga Range potassic lavas, East African Rift; Kampunzu et al. 1998), v. intersections between extensional and 


\section{Vaughan and Scarrow}

offsetting faults (e.g. alkaline rocks associated with the Canadian Cordilleran miogeocline; Goodfellow et al. 1995), vi. oblique rift zones (e.g. alkaline volcanism in the Dead Sea rift zone, Southeast Turkey; Alici et al. 2001), vii. rift flanks where $\beta$-factors are small (less than 1.2) (e.g. the North Sea; Latin and Waters 1991). What links these sites of magma transfer and emplacement is that they form in zones of transtension (strike-slip deformation that deviates from simple shear because of a component of extension orthogonal to the deformation zone, Dewey et al. 1998).

Lamentably few studies synthesise geochemical and structural data. Nonetheless, a close temporal and spatial association between magmatism generated from K-rich metasomatized lithospheric mantle and transcurrent shear has been documented at deep and shallow crustal levels in many tectonic settings worldwide (see below). Although a more comprehensive review is beyond the scope of this paper, some well-documented examples will serve to illustrate our case.

\section{Transtension}

In the Caledonian of Scotland and Ireland (Fig. 1), the initiation of Silurian-Devonian orogenparallel bulk sinistral transtension is coeval with the onset of an episode of K-rich magmatism across a width of the orogen from northwest Scotland to the north of England and eastern Ireland, a zone spanning $1000 \mathrm{~km}$ (Vaughan 1996). The range of magmatism is diverse, including shoshonitic lavas, hypabyssal and subvolcanic lamprophyres, and large volumes of Krich plutonic rocks. Sigmoidal pluton shapes in plan, en echelon dyke arrays, syn-magmatic deformation and juxtaposition of plutonic, hypabyssal and volcanic rocks suggest strongly that transtensional shear zones hosted these magmas (Hutton 1988a, Jacques and Reavy 1994, 


\section{Vaughan and Scarrow}

Vaughan 1996). In the Ross Sea, the potassic McMurdo dyke swarm of the Meander Intrusive Suite is coeval with a brief dextral transtensional phase that preceded full rifting (Rossetti et al. 2001, Rocchi et al. 2002). In Turkey (Savascin et al. 1994), alkaline magmatism occurred during dextral transtensional episodes along the Kirka-Afyon-Isparta structural trend, from Miocene to Recent (calc-alkaline magmatism occurs during compressive phases; the Cretaceous Antarctic Peninsula shows similar relationships; Scarrow et al. 1997). More recently still, sinistral strike slip faults associated with the transtensional development of the Lake Baikal rift in Siberia (Fig.1) localize K-rich monogenetic volcanoes (Delvaux et al. 1997, Lesne et al. 1998). Likewise, in the trans-Mexican volcanic belt (Fig. 1), potassic monogenetic volcanoes are aligned along arc-parallel fault associated with extension (Alaniz-Alvarez 1998) and sinistral strike-slip (Suter et al. 1995, Suter 1999). Carboniferous, high-K calc-alkaline plutons and potassic to ultrapotassic basalts coincide with a brief phase of extension (Apraiz and Eguiluz 2002) during sinistral strike-slip movement on the Ossa-Morena suture zone in central western Spain (Casquet et al., 2001).

Strike-slip

Contemporaneous intrusion of K-rich plutonic rocks and lamprophyres are directly related to strike-slip along the Elbe Zone of the Bohemian Massif (Wenzel et al., 2002). Triassic shoshonitic magmas are associated with sinistral strike-slip in the Dolomites of northern Italy (Sloman 1989) (Fig. 1). Mid-Cretaceous dextral strike-slip is associated with the emplacement of voluminous potassic granitic rocks in north-central British Columbia (Gabrielse 1991) (Fig. 1). In the Tertiary, Eocene emplacement of ultra-alkaline magma into strike-slip faults in eastern Paraguay was controlled by east-west trending dextral shear (Riccomini et al., 2001). In marine settings, Tertiary lamprophyres are associated with transform faults on the Sierra Leone rise in 
Vaughan and Scarrow

the Atlantic Ocean (Jones et al. 1991)(Fig. 1) and the Owen Fracture Zone ridge off Oman in the Indian Ocean (Whitmarsh et al 1974)(Fig. 1).

Model

McKenzie (1989) argued that, over geological timescales, perturbation of the asthenosphere during convection causes the first-formed small volumes of potassic melt to percolate up through the upper thermal boundary layer of this mantle. These small-volumes of melt freeze in the cooler top of the thermal boundary layer, the so-called mechanical boundary layer, forming a zone of lithospheric mantle that is rich in volatiles and incompatible elements. This enriched zone is easily fusible, i.e. close to its solidus, and is argued to be the source of the earliest magmas during advection of heat to the base of the lithosphere (Harry and Leeman 1995). Extreme compositional heterogeneities in this zone occur on 10-km-scales (e.g. Zhang et al. 2000 ), with a large range of compositions, e.g. $\varepsilon \mathrm{Sr}$ from -2 to +180 and $\varepsilon \mathrm{Nd}$ from +2 to -12 interpreted from potassic and ultrapotassic magmas in the Roman Province (Conticelli et al. 2002).

The tectonic associations outlined above suggest that K-rich alkaline magmatism is linked with small degrees of extension $(\beta \sim 1.2)$, and commonly is found in zones of transtension. The relationship between K-rich alkaline magmatism and small degrees of extension suggests a positive relationship between degree of metasomatism and ease of melting, and suggests that metsomatised mantle is close to the solidus for normal ranges of lithospheric basal temperature and thickness (e.g. Harry and Leeman 1995). Transtensional zones are associated with $\beta$-factors of c. 1.2 (e.g. 1.19-1.34 for the Dead Sea rift; Alzoubi and ten Brink 2002; Fig. 1), which is more than enough to achieve adiabatic decompression partial melting in the upper asthenospheric 
mantle (Pedersen 1994) or in the metasomatically altered lithospheric mantle at depths $>60 \mathrm{~km}$ (Harry and Leeman 1995).

The case is simple for bulk transtension (Fig. 2i). However, bulk simple shear will not produce extension. Fortunately, the lithosphere and mantle are not rheologically homogeneous. Recent studies show that mantle seismic anisotropy is common (Tommasi and Vauchez 2001), probably reflecting mantle flow structures produced during orogenesis, and studies of transform fault behaviour in areas of strong oceanic lithosphere indicate that stress fields cause strike-slip faults to avoid very thick and strong lithosphere (Ligi et al. 2002). We propose that for lithosphere and upper mantle with realistic variations in rheological contrast (e.g. cratons separated by mobile belts or upper mantle with pre-existing anisotropy (Fig. 2ii) stress trajectories during bulk simple shear will deviate to produce localized zones of transpression and transtension (of probable Type B, Fossen and Tikoff 1998) (Fig. 2ii). For example, strike-slip dominates west of the Siberian Craton, whereas to the south, a zone of extension to transtension (forming the Baikal Rift) is active (A. Vauchez pers. comm. 2002; Lesne et al. 1998). Adiabatically induced melting is likely to occur first in the most volatile-rich and most easily fusible volumes of the lithospheric mantle (Fig. 2b). So, during the initiation of bulk transtension or horizontal simple shear, adiabatic decompression in zones of transtension will trigger partial melting in small-scale (i.e. $10-\mathrm{km}$ ) zones of metasomatically enriched mantle at the base of the lithosphere, at $\beta$-factors of $\mathrm{c}$. 1.2. Transtension will nucleate dykes in the manner of tension veins in a homogeneous deforming solid. Magma-driven fractures will then propagate rapidly to upper levels of the lithosphere, nucleating a zone of lithospheric weakness that will focus shear strain and form the zone of initiation of a strike-slip fault (Fig. 2c). Shear systems may show initial tensional arrays of K-rich basaltic dykes cut by later more planar P shear zones hosting granite magma (e.g. 


\section{Vaughan and Scarrow}

Vaughan 1996; Fig. 2c). In this way, K-rich mantle metasomatism controls the location of faulting and the resulting K-rich magmas control fault propagation.

\section{Discussion}

Timing relationships are key to our model. So far it has not been possible to demonstrate that bulk lithospheric shearing predates magmatism, although in the best-documented examples, i.e. the Caledonian (Vaughan 1996) and the Ross Sea (Rossetti et al. 2001, Rocchi et al. 2002), magmatism and transtension are at least coeval. Vauchez et al. (1997) have also proposed mutual relationships between strike-slip faulting and potassic magmatism, and Neves et al. (1996) have suggested that magma accumulations in the lithosphere form nuclei for transcurrent shear zones, but further work is required. A key consequence of our model is that magmatism associated with transtension in the early stages of lithospheric strike-slip or rifting will focus strain and nucleate major faults. Heterogeneities in K-rich metasomatism will fundamentally control the local yield strength of lithosphere, even if over a very large scale, thermal effects are important, such as those induced by delamination of the base of the lithosphere. Another consequence is that decompression melting of metasomatised mantle and subsequent alkaline magmatism may also control rift localisation.

Given that this model concentrates strain in a narrow zone, defusing more distributed lithospheric shear, it could be argued that once a fault system is initiated in this way it should become the main focus of strike-slip shear at the expense of formation of any further systems. This indeed appears to be the case for the Red River shear zone in China (Fig. 1), where an alkaline-magma-lubricated zone is taking up much of the differential movement associated with the extrusion of Southeast Asia during the India-Eurasia collision (Zhang and Scharer 1999). 


\section{Vaughan and Scarrow}

Strike slip faults nucleated in this way will create space for the accumulation of K-rich granite magma and a site of preservation of continental crust. Volumetrically, potassic granites, such as the Newer Granites of the Caledonide orogen (e.g. Soper 1986), form a significant proportion of the crust, particularly in post-orogenic settings. The intimate connection between potassic magmatism and strike-slip faulting argued for here suggests that the relationship has the characteristics of a tectonomagmatic association such as the orogenic magma series, and this echoes recent suggestions that strike-slip related K-rich magmatism is common in post-orogenic settings (Bonin et al 1998). This represents a hitherto unrecognised tectonomagmatic association as important as, for example, the ocean island magma series. Finally, our model, although not invalidating the generally accepted view of fault control of magma transport and accommodation, proposes the converse i.e. that K-rich magmatism, generated at the base of metasomatized lithosphere by regional or local transtension, controls the nucleation and location of transcurrent fault systems. Even though resulting magmatism will be coeval with fault development and volcanoes will appear fault-controlled, our model suggests the opposite. Magmatism will control fault timing and location, i.e., faults will be volcano-controlled. The distinction may appear to be a subtle one, but our model allows for the formation of new faults in unfaulted lithosphere, which has a bearing on the formation of plates (Bercovici 2003).

\section{Conclusions}

i. A close temporal and spatial association exists between K-rich magmatism and transtension, having been documented at deep and shallow crustal levels in many tectonic settings worldwide.

ii. Our new model indicates that bulk transtension, or local transtension during bulk simple shear, of heterogeneously enriched lithospheric mantle triggers localised K-rich magmatism. 


\section{Vaughan and Scarrow}

iii. The resulting magma-driven fractures focus strain and cause nucleation of lithospherescale transcurrent faults.

iv. This association represents a hitherto unrecognised genetic relationship between tectonics and magmatism as significant as, for example, the ocean island magma series.

\section{Acknowledgements}

We would like to thank Philip Leat, Adolphe Nicholas, Alain Vauchez, and Renoud Vissers for reviews and suggestions that substantially improved the manuscript. 
Vaughan and Scarrow

References

Adiyaman, O., Chorowicz, J. and Kose, O., 1998. Relationships between volcanic patterns and neotectonics in Eastern Anatolia from analysis of satellite images and DEM. Journal of Volcanology and Geothermal Research, 85, 17-32.

Alaniz-Alvarez, S.A., Nieto-Samaniego, A.F. and Ferrari, L., 1998. Effect of strain rate in the distribution of monogenetic and polygenetic volcanism in the TransMexican volcanic belt. Geology, 26, 591-594.

Alici, P., Temel, A., Gourgaud, A., Vidal, P. and Gundogdu, M.N. 2001. Quaternary tholeiitic to alkaline volcanism in the Karasu Valley, Dead Sea rift zone, Southeast Turkey: Sr-Nd$\mathrm{Pb}-\mathrm{O}$ isotopic and trace-element approaches to crust-mantle interaction. International Geology Review, 43, 120-138.

Al-Zoubi, A. and ten Brink U., 2002. Lower crustal flow and the role of shear in basin subsidence: an example from the Dead Sea basin. Earth and Planetary Science Letters, 199, 67-79.

Anderson, E.M., 1951. The dynamics of faulting and dyke formation with application to Britain. 2nd edition. Oliver and Boyd, Edinburgh.

Apraiz, A. and Eguiluz, L., 2002. Hercynian tectono-thermal evolution associated with crustal extension and exhumation of the Lora del Rio metamorphic core complex (Ossa-Morena zone, Iberian Massif, SW Spain). International Journal of Earth Sciences, 91, 76-92.

Balk, R., 1937. Structural behaviour of igneous rocks. Geological Society of America Memoir, 5, GSA, Boulder.

Benn, K., Sawyer, E.W. and Cruden, A.R., 1998. Preface to special issue on "Extraction, transport and emplacement of granitic magmas". Journal of Structural Geology, 20, v-ix. 
Vaughan and Scarrow

Bercovici, D., 2003. The generation of plate tectonics from mantle convection. Earth and Planetary Science Letters, 205, 107-121.

Bonin, B.L, Azzouni-Sekkal, A., Bussy, F. and Ferrag, S., 1998. Alkali-calcic and alkaline postorogenic (PO) granite magmatism: petrologic constraints and geodynamic settings. Lithos, 45, 45-70.

Bouchez, J.-L., 1997. Granite is never isotropic: an introduction to AMS studies of granitic rocks. In: Granite: from segregation of melt to emplacement fabrics. (J.-L. Bouchez, D.W.H. Hutton, and W.E. Stephens, eds), pp. 95-112, Kluwer, Dordrecht, the Netherlands.

Casquet, C., Galindo, C., Tornos, F., Velasco, F. and Canales, A., 2001. The Aguablanca Cu-Ni ore deposit (Extremadura, Spain), a case of synorogenic orthomagmatic mineralization: age and isotope composition of magmas (Sr-Nd) and ore (S). Ore Geology Reviews, 18, $237-250$.

Conticelli, S., D'Antonio, M., Pinarelli, L. and Civetta, L., 2002. Source contamination and mantle heterogeneity in the genesis of Italian potassic and ultrapotassic volcanic rocks: $\mathrm{Sr}-\mathrm{Nd}-\mathrm{Pb}$ isotope data from Roman Province and Southern Tuscany. Mineralogy and Petrology, 74, 189-222.

Delvaux, D., Moeys, R., Stapel, G., Petit, C., Levi, K., Miroschnichenko, A., Ruzhich, V. and San'kov, V., 1997. Palaeostress reconstructions and geodynamics of the Baikal region, Central Asia, Part II. Cenozoic rifting. Tectonophysics, 282, 1-38.

Dewey, J.F., Holdsworth, R.E. and Strachan, R.A., 1998. Transpression and transtension zones. In: Continental transpressional and transtensional tectonics. (R.E. Holdsworth, R.A. Strachan, and J.F. Dewey, eds), pp. 1-14, Geological Society Special Publication, 135. 
Vaughan and Scarrow

Fossen, H. and Tikoff, B., 1998. Extended models of transpression and transtension, and application to tectonic settings. In: Continental transpressional and transtensional tectonics. (R.E. Holdsworth, R.A. Strachan, and J.F. Dewey, eds), pp. 15-33, Special Publication of the Geological Society, London, 135.

Gibson, S.A., Thompson, R.N., Leat, P.T., Morrison, M.A., Hendry, G.L., Dickin, A.P. and Mitchell, J.G., 1993. Ultrapotassic magmas along the flanks of the Oligo-Miocene Rio Grande rift, USA: monitors of the zone of lithospheric mantle extension and thinning beneath a continental rift. Journal of Petrology, 34, 187-228.

Gibson, S.A., Thompson, R.N., Weska, R.K., Dickin, A.P. and Leonardos, O.H., 1997. Late Cretaceous rift-related upwelling and melting of the Trinidade starting mantle plume head beneath western Brazil. Contributions to Mineralogy and Petrology, 126, 303-314.

Gabrielse, H., 1991. Late Paleozoic and Mesozoic terrane interactions in north-central British Columbia. Canadian Journal of Earth Sciences, 28, 947-957.

Gîrbacea, R. and Frisch, W., 1998. Slab in the wrong place: lower lithospheric mantle delamination in the last stage of the Eastern Carpathian subduction retreat. Geology, 26, $611-614$.

Goodfellow, W.D., Cecile, M.P. and Leybourne M.I., 1995. Geochemistry, petrogenesis, and tectonic setting of Lower Paleozoic alkalic and potassic volcanic rocks, northern Canadian Cordilleran Miogeocline. Canadian Journal of Earth Sciences, 32, 12361254.

Harry, D.L. \& Leeman, W.P., 1995. Partial melting of melt metasomatized subcontinental mantle and the magma source potential of the lower lithosphere. Journal of Geophysical Research, 100, 10255-10269. 
Vaughan and Scarrow

Hutton, D.H.W., 1982. A tectonic model for the emplacement of the Main Donegal Granite, NW Ireland. Journal of the Geological Society, London, 139, 615-631.

Hutton, D.H.W., 1988a. Granite emplacement mechanisms and tectonic controls: Inferences from deformation studies. Transactions of the Royal Society of Edinburgh, Earth Sciences, 79, 245-255.

Hutton, D.H.W., 1988b. Igneous emplacement in a shear zone termination: the biotite granite at Strontian, Scotland. Geological Society of America Bulletin, 100, 1392-1399.

Hutton, D.H.W., Dempster, T.J., Brown, P.E. and Becker, S.D., 1990. A new mechanism of granite emplacement: intrusion in active extensional shear zones. Nature, 343, 452-455.

Ingram, G.M. and Hutton, D.H.W., 1994. The Great Tonalite Sill: emplacement into a contractional shear zone and implications for Late Cretaceous to early Eocene tectonics in southeastern Alaska and British Columbia. Geological Society of America Bulletin, 106, 715-728.

Jacques, J.M. and Reavy, R.J., 1994. Caledonian plutonism and major lineaments in the SW Scottish Highlands. Journal of the Geological Society, London, 151, 955-969.

Jones, E.J.W., Goddard, D.A., Mitchell, J.G. \& Banner, F.T., 1991. Lamprophyric volcanism of Cenozoic age on the Sierra Leone Rise: implications for regional tectonics and the stratigraphic time scale. Marine Geology, 99, 19-28.

Kampunzu, A.B., Bonhomme, M.G. and Kanika M., 1998. Geochronology of volcanic rocks and evolution of the Cenozoic western branch of the East African rift system. Journal of African Earth Sciences, 26, 441-461.

Latin, D. and Waters F.G., 1991. Melt generation during rifting in the North Sea. Nature, 351, $559-562$. 
Vaughan and Scarrow

Lesne, O., Calais, E.and Déverchère, J., 1998. Finite element modeling of crustal deformation in the Baikal rift zone: New insights into the active-passive rifting debate. Tectonophysics, 289, 327-345.

Ligi, M., Bonatti, E., Gasperini, L. and Poliakov, A.N.B., 2002. Oceanic broad multifault transform plate boundaries. Geology, 30, 11-14.

McKenzie, D.P., 1989. Some remarks on the movement of small melt fractions in the mantle. Earth and Planetary Science Letters, 95, 53-72.

McKenzie, D.P. and Bickle, M.J., 1988. The volume and composition of melt generated by extension of the lithosphere. Journal of Petrology, 26, 625-679.

Moyen, J-.F., Nédelec, A., Martin, H. and Jayananda, M., 2003. Syntectonic granite emplacement at different structural levels: the Closepet granite, South India. Journal of Structural Geology, 25, 611-631.

Neves, S.P., Vauchez, A. and Archanjo, C.J., 1996. Shear zone-controlled magma emplacement or magma-assisted nucleation of shear zones? Insights from northeast Brazil. Tectonophysics, 262, 349-364.

Paterson, S.R. and Vernon, R.H., 1995. Bursting the bubble of ballooning plutons: a return to nested diapirs emplaced by multiple processes. Geological Society of America Bulletin, 107, 1356-1380.

Pedersen, T., 1994. Some remarks on lithospheric forces and decompression magmatism. Tectonophysics, 240, 11-19.

Pe-Piper, G., Koukouvelas, I. and Piper, D.J.W., 1998. Synkinematic granite emplacement in a shear zone: The Pleasant Hills pluton, Canadian Appalachians. Geological Society of America Bulletin, 110, 523-536. 
Petford, N., 1996. Dykes or diapirs? Transactions of the Royal Society, Edinburgh: Earth Sciences, 87, 105-114.

Quick, J.E., Sinigoi, S. and Mayer, A., 1994. Emplacement dynamics of a large mafic intrusion in the lower crust, Ivrea-Verbano Zone, northern Italy. Journal of Geophysical Research, 99, 21559-21573.

Riccomini, C., Velazquez, V.F., and Gomes, C.D., 2001. Cenozoic lithospheric faulting in the Asunción, eastern Paraguay. Journal of South American Earth Sciences, 14, 625-630.

Rocchi, S., Armienti, P., D’Orazio, M., Tonarini, S., Wijbrans, J.R. and Di Vincenzo, G., 2002. Cenozoic magmatism in the western Ross Embayment: Role of mantle plume versus plate dynamics in the development of the West Antarctic Rift System. Journal of Geophysical Research, 107, doi:10.1029/2001JB000515.

Rossetti, F., Storti, F., Salvini, F., 2000. Cenozoic noncoaxial transtension along the western shoulder of the Ross Sea, Antarctica, and the emplacement of McMurdo dyke arrays. Terra Nova, 12, 60-66.

Savascin, M., Birsoy, R. Dag, N. and Nohutcu E., 1994. Kirka-Afyon-Isparta structural trend and alkaline rock associations (Anatolia). In: Proceedings, 7th congress of the Geological Society of Greece, with emphasis on the geology of Macedonia and Thrace. (D. Mountrakis, ed.), pp. 89-98, Bulletin of the Geological Society of Greece, 30.

Scarrow, J.H., Vaughan, A.P.M. and Leat, P.T., 1997. Ridge-trench collision induced switching of arc tectonics and magma sources: clues from Antarctic Peninsula mafic dykes. Terra Nova, 9, 255-259.

Sloman, L.E., 1989. Triassic shoshonites from the Dolomites, northern Italy: alkaline arc rocks in a strike-slip setting. Journal of Geophysical Research, 94, 4655-4666. 
Vaughan and Scarrow

Soper, N.J., 1986. The Newer Granite problem: a geotectonic view. Geological Magazine, 123, $227-236$.

Suter, M., 1999. Effect of strain rate in the distribution of monogenetic and polygenetic volcanism in the TransMexican volcanic belt: comments and reply. Geology, 27, 571.

Suter, M., Quintero-Legorreta, O., Lopez-Martinez, M., Aguirre-Diaz, G. and Farrar, E., 1995. The Acambay graben: active intra-arc extension in the trans-Mexican volcanic belt, Mexico. Tectonics, 14, 1245-1262.

Tchalenko, J.S., 1970. Similarities between shear zones of different magnitudes. Geological Society of America Bulletin, 81, 1625-1640.

ten Brink, U.S., Benavraham, Z., Bell, R.E., Hassouneh, M., Coleman, D.F., Andreasen, G., Tibor, G. and Coakley, B., 1993. Structure of the Dead-Sea pull-apart basin from gravity analyses. Journal of Geophysical Research-Solid Earth, 98, 21877-21894.

Tommasi, A. and Vauchez, A., 2001. Continental rifting parallel to ancient collisional belts: an effect of the mechanical anisotropy of the lithospheric mantle. Earth and Planetary Science Letters, 185, 199-210.

Vauchez, A., Neves, S.P. and Bouchez, J.L. 1997. Transcurrent shear zones and magma emplacement in Neoproterozoic belts of Brazil. In: Granite: from melt segregation to emplacement fabrics (J.L. Bouchez, D.H.W. Hutton and W.E. Stephens, eds), pp. 275293, Kluwer, Dordrecht, the Netherlands.

Vaughan, A.P.M., 1996. A tectonomagmatic model for the genesis and emplacement of Caledonian calc-alkaline lamprophyres. Journal of the Geological Society, London, 153, $613-623$.

Wenzel, T., Oberhansli, R. and Metzger, K., 2000. K-rich plutonic rocks and lamprophyres from 
Vaughan and Scarrow

the Meissen Massif (northern Bohemian Massif): Geochemical evidence for variably enriched lithospheric mantle sources. Neues Jahrbuch fur Mineralogie-Abhandlungen, 175, 249-293.

Whitmarsh, R.B., Wiser, O. and Shipboard Party, 1974. Site 224. Initial Report of the Ocean Drilling Project, 23, 383-419.

Wilson, M., 1989. Igneous Petrogenesis. Unwin Hyman, London.

Zhang, L-.S. and Schärer, U., 1999. Age and origin of magmatism along the Cenozoic Red River shear belt, China. Contributions to Mineralogy and Petrology, 134, 67-85.

Zhang, Z.C., Lin, Z., Li, Z.N., Li, S.C., Li, Z.M. and Wang, X.Z., 2000. Extreme mantle heterogeneity beneath the Jingpohu area, northeastern China - geochemical evidence of Holocene basaltic rock. Acta Geologica Sinica-English Edition, 74, 163-175.

Figure Captions

Figure 1: Distribution of K-rich magmatism localities mentioned in the text and tectonothermal regimes associated with emplacement.

Figure 2: Notional lithospheric blocks undergoing bulk horizontal shear strain. i) Regional transtension a) Contoured ornament shows stylised heterogeneous enrichment of the lithospheric mantle at base of lithosphere $>60 \mathrm{~km}$ thick (Harry and Leeman 1995). Darker suggests greater enrichment. b) Adiabatic decompression melting under transtension of metasomatized layer in zone of maximum enrichment. c) Ascent of potassic magma-driven fractures to shallow levels. 


\section{Vaughan and Scarrow}

Tensional dykes are initially emplaced, with associated volcanoes, followed by break-through of Primary or P-shear (after Tchalenko 1970), which propagates away from the zone of nucleation, forming a new, discrete, transtensional strike-slip shear zone, in this case sinistral. ii) Bulk simple shear but with pre-existing mantle anisotropy and lithospheric mobile belt between cratonic blocks. a) as for i), b) partial melting as before but in localized zone of transtension associated with stress deviation. c) As for i) but P-shear propagates away from the localized transtensional zone of nucleation, to form a new, discrete, strike-slip shear zone, not characterized by transtension, in adjacent blocks. 


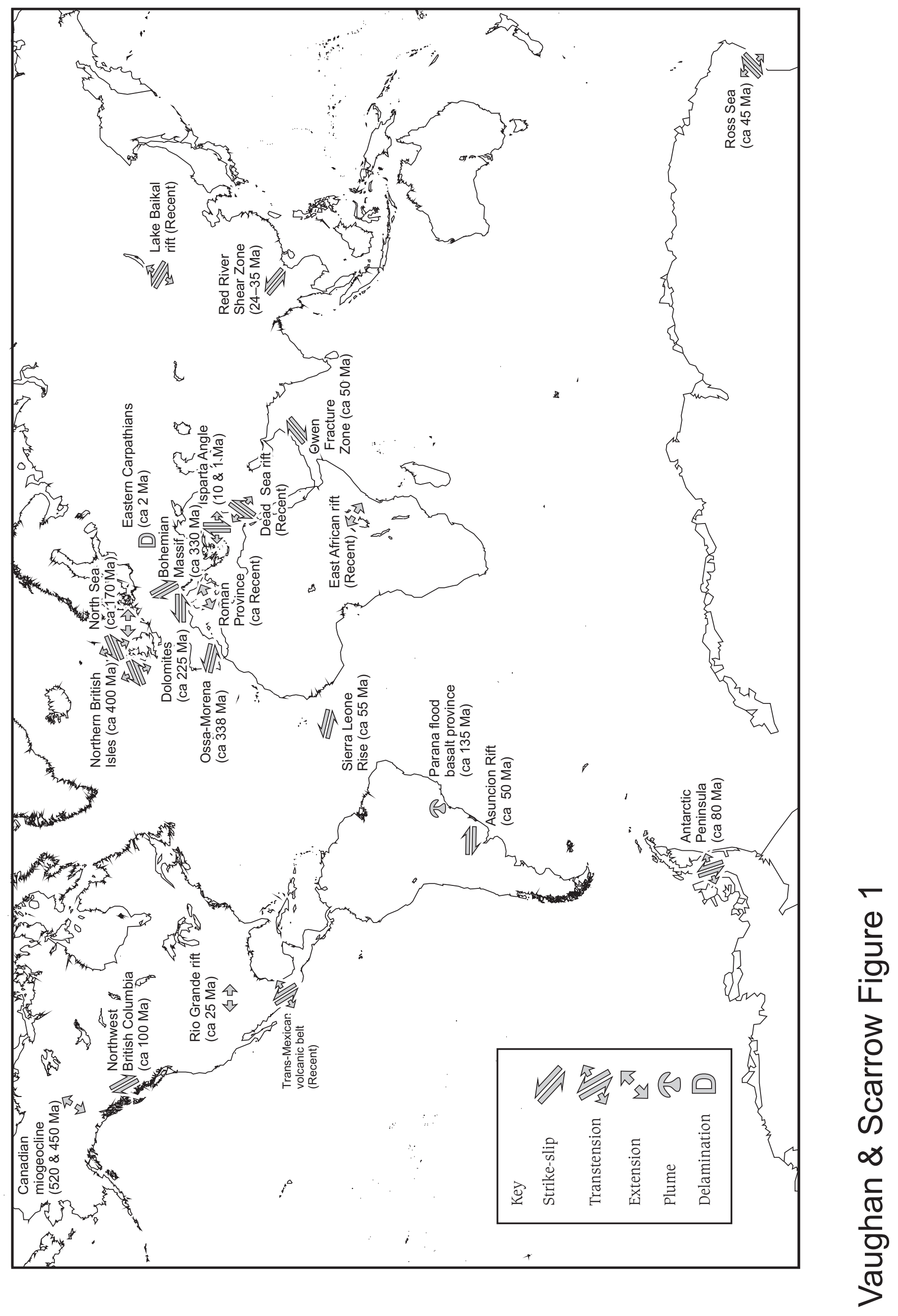



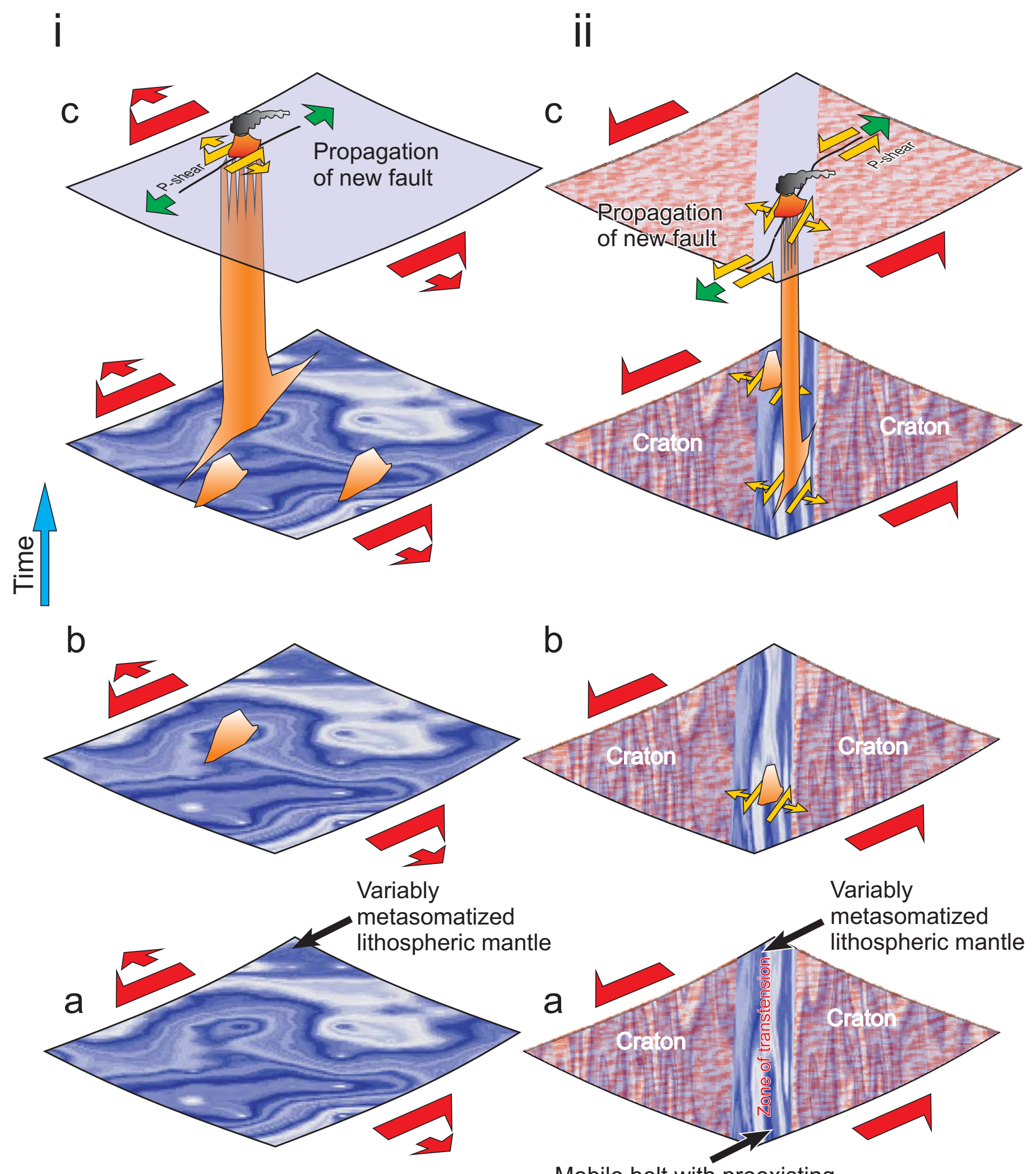

Mobile belt with preexisting lithospheric mantle anisotropy

\section{Vaughan \& Scarrow Figure 2}

